\title{
UNDERSTANDING AND SUPPORTING FULL-TIME NON-TENURE-TRACK FACULTY
}

A NEEDED CHANGE

Genevieve G. Shaker, Megan M. Palmer,

Nancy Van Note Chism, Indiana University-Purdue University Indianapolis

As the face of the American faculty profession changes, targeted academic development becomes more important. A phenomenological qualitative study of full-time, non-tenure-track faculty in English portrays an experience characterized by a love of teaching but fraught with professional challenges stemming from low status and poor reward and recognition structures. These data provide the point of departure for recommendations on expanding organizational and faculty development strategies for supporting, integrating, and encouraging full-time, non-tenure-track faculty.

The literature on faculty development is built around the traditional notion of the faculty member progressing along a stable career line, enjoying equal status with other faculty colleagues, and having relative autonomy and variety in teaching assignments. Faculty development centers often do workshops on documenting tenure dossiers, advice to developers stresses engaging "respected faculty leaders" in programming or on advisory boards, and workshops often assume that participants are free to alter their course syllabi, change course assessment methods, and develop new offerings. Enter the contingent faculty member, now among the majority of newly hired faculty members in the United States (Schuster \& Finklestein, 2006). 
In qualitative and mixed-method studies of full-time, non-tenure-track (FTNT) faculty, the emphasis has usually been quite broad (Baldwin $\&$ Chronister, 2001) and has not attended to FTNT faculty in depth at the discipline, institution, department, or individual level. Schuster and Finkelstein (2006) argued the FTNT trend may be "the most consequential but most under-investigated faculty-related phenomenon of the past several decades" (p. 355). In spite of the growing body of scholarship about the FTNT, the phenomenon remains well stocked with opportunities for further research. This qualitative study was guided by the question: What are the essential features of the experience of being FTNT faculty? Our goal is to understand more fully the conditions in which FTNT faculty work for the purpose of customizing development programs to their needs.

\section{Context of the Study}

The American public's unease with the necessity for and practicality of tenure, declining government financing for higher education, an abundance of Ph.D. recipients, changing patterns of student enrollment, concern about overreliance on part-time faculty, and new curricular demands all have contributed to an environment conducive to the hiring and continued employment of FTNT faculty (Baldwin \& Chronister, 2001). In 1987, 8 percent of all full-time faculty at higher education institutions worked off the tenure track; by 2003, FTNT faculty accounted for 21 percent of faculty nationwide. And in 2003, FTNT faculty represented 59 percent of newly hired instructors, up from 51 percent a decade earlier (Schuster \& Finklestein, 2006). Today, as institutions face diminished budgets, they report they are just as likely to consider cuts in individual tenure-line appointments as in nontenure positions (Association of Public and LandGrant Universities, 2009), suggesting that FTNT faculty are now deeply embedded in their institutions.

All disciplines are affected by this shift (National Center for Education Statistics, 2005), but few are more concerned about and fundamentally affected by reliance on contingent faculty than English departments (Association of Departments of English, 1999; Bousquet, Scott, \& Parascondola, 2004; Cayton, 1991; Laurence, 2001; Modern Language Association \& Association of Departments of English, 2008). What happens in English, with its near universally required undergraduate writing courses and the foundational skills transmitted in those courses, has ripple effects across campus. It appears that English, in its reliance on FTNT faculty, is not the exception but the rule throughout academe 
(AFT Higher Education, 2009; Schuster \& Finkelstein, 2006), and for this reason, it is the setting for this chapter.

\section{Literature Review}

Schuster and Finkelstein (2006) found that FTNT faculty were more likely to focus on teaching than research and were both younger and more proportionately female than tenure-eligible faculty. Baldwin and Chronister (2001) and others (Evans, 1996; Harper, Baldwin, Gansneder, \& Chronister, 2001; Smith \& Hixson, 1987) studied select aspects of the FTNT experience, finding these faculty to be diverse in background, experience, and professional responsibilities. Dual labor market theory has been used to seek theoretical grounding for the circumstances of FTNT employment, arguing that a two-tiered system explains, to some extent, the nontenure experience (Roemer \& Schnitz, 1982; Rosenblum \& Rosenblum, 1996; Smith \& Hixson, 1987). FTNT employment looks very much like a secondary market when it is unstable, exists in poor conditions, is based on tasks that tenured faculty do not want to complete, lacks opportunities for professional or scholarly development, offers fewer professional perks than those afforded tenure-line faculty, and provides limited paths for advancement (Roemer \& Schnitz, 1982).

Using data from the National Study of Postsecondary Faculty, one study criticized institutions for failing to attend appropriately to the effects of the FTNT appointment on diminished individual productivity and commitment (Bland, Center, Finstad, Risbey, \& Staples, 2006). Administrators surveyed in a national study recognized FTNT faculty for their important contributions in the classroom and beyond, despite their poor salaries and low status (Center for the Education of Women, 2007). As a group, FTNT faculty have been perceived as a threat to faculty power, norms, and job markets based on assumptions that they have poor institutional ties, are disempowered by their lack of tenure, and fill positions that might otherwise be tenure-track (Finkin, 1996; McPherson \& Schapiro, 1999). Scholars have begun to use data to examine the effects of FTNT faculty on students (Ehrenberg \& Zhang, 2005), finding a correlation between these faculty and lower graduation rates. Critics, however, often do little to accommodate for the professional identity issues of nontenure-track faculty resulting from their employment conditions (Levin, Shaker, \& Wagoner, 2010) or to recognize the central role FTNT faculty play when it comes to accomplishing the core missions of colleges and universities. Agreeing that FTNT faculty are in academe to stay, a range of best practices for employment policies, including longer contracts and 
promotion structures, has been proposed and endorsed (Baldwin \& Chronister, 2001; Center for the Education of Women, 2007; Gappa, Austin, \& Trice, 2007; Rhoades \& Maitland, 2008; Tolbert, 1998).

\section{Methods}

The best way to deeply consider being FTNT faculty was nearness to that experience. Thus phenomenology, as a philosophy and a method, was selected for its "focus on exploring how human beings make sense of experience and transform the experience into consciousness" (Patton, 2002 , p. 104) and attention "to mak[ing] the invisible visible" (Kvale, 1996, p. 53). In this research, the essential features of FTNT "facultyness" were deeply explored through compilation, analysis, and interpretation of the lived reality of English FTNT faculty members.

The three public universities in this study spanned two states, ranged from twenty thousand to thirty-five thousand students, and were doctoral or research institutions. One was unionized; two were in urban settings. With department support and through the administration of questionnaires, faculty participants were purposefully selected to create a sample stratified in gender, academic experience, educational degree, and professional responsibility. All study faculty were engaged with rhetoric and composition programs to some degree, but many also had administrative responsibilities or taught classes in subjects other than first-year writing.

Eighteen FTNT English faculty from the three institutions were interviewed during the second half of 2007. Of interest in a phenomenological study is the confluence of participant and phenomenon-"how they perceive it, describe it, feel about it, judge it, remember it, make sense of it, and talk about it with others" (Patton, 2002, p. 104). Thus, participants, interviewed once for between one and three hours, were asked to reflect deeply and speak openly about being FTNT faculty members.

The analysis was based on a series of steps adapted from Carspecken (1996), Creswell (1998, 2003), and Moustakas (1994). Interviews were transcribed and then reviewed by the researcher and participants. Raw codes were developed and reduced to eliminate unsubstantiated or underdeveloped ideas. Clustering of remaining codes formed themes and connections between the essential features of being FTNT in English and systems governing and relating to that experience were sought. Just as they reviewed interview transcriptions, participants read the study findings and shared comments.

This study had its limitations, including its small size and scope. The research lacked a comparative perspective and did not incorporate 
perspectives of part-time, tenure-track, and tenured faculty, or those in other disciplines. Because qualitative studies seek depth rather than breadth and do not require a large sample or comparative element for the findings to have value (Patton, 2002), we decided to attend deeply to the lived experiences of the selected group of faculty rather than expand the study to address its limitations. Because we focused on one discipline, the study findings were affected by English-specific conditions that may or may not be relevant to the other disciplinary contexts of FTNT work. However, our conclusions align with what is thought and reported to be true about the broader FTNT faculty experience (Shaker, 2008).

\section{Results}

The FTNT faculty followed nontraditional academic career paths, often situating personal priorities before professional advancement, and they planned to continue working in higher education. Their hopes and visions for the future, however, varied based on possession or lack of a terminal degree. One respondent stated,

I think I always wanted to teach. I come from a family of teachers. I'm one of those people who probably doesn't thrive in the marketplace because I love the role of ideas and I'm not eminently practical about things. I've never been real job oriented or career oriented. I've more wanted to do things where I've felt like I've made a difference, and it's taken me a long time to realize that that may not be the best thing for me professionally, or that my professional future may not be the same as what makes me happy or satisfied. But I just ... I love talking to students. I love interacting with students. I love classroom discussions. I've just always thrived on that culture and that environment.

FTNT faculty struggled with heavy workloads, salary structures perceived to be out of balance with their contributions and often underdeveloped reappointment and promotion policies. Nevertheless, they evidenced high levels of confidence in job security due to the quality of their contributions and their field's importance in the curriculum. Another respondent replied, "It's too much. It is too much to be entirely fair to the students you have. It is too much work for one person to handle at given points of the semester, particularly at the end when ... other faculty can run their tests through Scantron machines, and we are literally grading hundreds of papers during finals week. Even if they're papers that we've seen drafts of before, that's a lot of work, and it's a lot of responsibility. It is too much work." 
Within composition programs, FTNT faculty felt valued, understood, and influential. In their departments, they reported a measure of respect and protection. At the institution level, participants described some marginalization and underappreciation, but responses were institution specific. According to one faculty member, "Tenure-track people, mostly in other departments ... have no idea. The tenure-track people in the English department know about the hard work that we do, and they're relieved because they don't want to teach those freshman classes, and they know they get us on the cheap. Somebody in art or history or psychology or criminal justice or whatever, they don't know. They've got their idea of what the ivory tower is, and we don't fit into it."

The FTNT experience in English was negatively affected by the position of composition in the discipline. Moreover, the positioning of the FTNT faculty in composition appeared to exacerbate and perpetuate disciplinary divisions, as indicated by the following statement: "What they really need to do is open more tenure lines and recognize that teaching composition is as valid as teaching a class on Milton and is more important really, because who walks away with more skills? The student who's had a research writing class, and knows how to use the research library and all the databases, and put together a number of different types of writings, from PowerPoint presentations to pamphlets to term papers? Or the person who can quote Milton? And, not that I don't think that the Milton class is important too. It is."

Although most participants professed stronger disciplinary than institutional loyalties, their close connections to students, workplaces, and communities were repeatedly demonstrated. Rationales for disciplinary prioritization, moreover, hinged on what the discipline enabled them to do, not who it enabled them to be.

FTNT second-class status was amplified by lingering and outdated stereotypes about "the faculty" and professorial work. These stereotypes had a harmful effect on FTNT faculty work experiences and self-perceptions, particularly participants' sense of worth and confidence. As one faculty member stated: "I think there was one point where they were saying 'faculty and [FTNT people].' Whereas, we have the same obligations as faculty do. We're faculty for all practical purposes, because in this particular meeting [the chair] had been delineating 'faculty' and '[FTNT people].' But the [FTNT people] didn't know they were supposed to participate in graduation, because the language of the meeting seemed to imply that [FTNT people] were not faculty."

Despite undesirable aspects of FTNT work-life, faculty chose to continue in these appointments because they loved teaching, were committed 
to students, and believed in serving society; they opted to cope and manage the difficult components of the work rather than surrender their positions. One respondent expressed, "I'm sure you've gathered, people who teach at the contract level, they're not trying to climb the ladder, madly trying to get over the top of everybody else. They're looking for an environment in which they can feel useful and content with what they do and feel like they're making a difference."

\section{Discussion}

Collectively, the experience described by FTNT faculty portrays a career characterized by maintenance of a tenuous balance between the positive and negative-positioning each individual on a shifting scale with potential to move in one direction or another. FTNT faculty were fulfilled by their work. Yet their experiences were nuanced and at times emotionally draining. Although they expressed broadly positive sentiments about being FTNT faculty, nagging doubts threatened their equilibrium on a daily basis. Their concerns often originated from externally governed aspects of their work and workplace, including professorial stereotypes, compensation levels, and heavy workload. Fluctuating emotions and personal circumstances as well as contextual factors mandated constant need for readjustment and revalidation. Essentially FTNT faculty were engaged in an ongoing balancing act in which much could influence their emotional stability and mental well-being.

\section{Recommendations}

Factors in the FTNT experience that are institutionally affected may be moderated, modified, or supported by academic developers.

\section{For Organizational Development}

Those working in organizational development are ideally positioned to play an active role in several issues that influence the effectiveness, satisfaction, and growth of FTNT faculty members. By providing support, practical suggestions for change, and information from the scholarly literature, developers can work to bring about improvement in the environment of FTNT faculty on multiple fronts, including tenure, appointments, stereotypes and status distinctions, communication, and participation.

The findings of this study support a substantial reconsideration of the continued viability of tenure in American higher education. It is clear from the participants' struggles to endure their secondary status that 
parity among today's faculty population is impossible in the current, tenure-emphasizing context. So long as disregard for academe's egalitarian principles continues and outdated conceptions of faculty life are perpetuated, the bifurcation will continue. Faculty divides will become progressively more intractable as time passes. Both nationally and at their own institutions, developers can help to raise awareness of the work of scholars who have analyzed the question of tenure and made helpful recommendations (Chait, 2002; Finkin, 1996; Plater, 2008; Rice, 2006). They can serve as local advocates in calling on their institutions to take a hard look at what tenure is, what it should be, and whether it should be at all.

Should the system continue as it is with the placement of faculty in non-tenure-eligible roles, a series of improvements is necessary. Institutions, perhaps with help from scholars, professional organizations, and unions, need to fully develop and refine the policies and systems governing these appointments. Developers can take their lead from this study and those of other scholars (Baldwin \& Chronister, 2001; Center for the Education of Women, 2007; Gappa et al., 2007; Rhoades \& Maitland, 2008) to support implementation of the following: renewable multiyear contracts with clear evaluation standards following an established probationary period, professorial titles with a sequential rank promotion system featuring well-documented guidelines and criteria, and equitable salaries with some compensation for the lack of security afforded by tenure.

As part of their advocacy role, developers working at the organizational level can help to identify ways in which the culture of the institution is perpetuating inequality at the expense of educational effectiveness. The questioning of stereotypes about faculty life is critical for creating an equitable academic workforce and respecting all those doing the work of teaching, research, and service in America's universities. Going forward, a fair representation of what it is to be faculty will encourage FTNT and other nontraditional faculty to focus on their work and not the dated conceptions surrounding their appointments. Developers can help to dispel the false and damaging notion that only those in the tenure ranks are the "regular" or "normal" faculty-distinctions that should be disregarded. They also might champion those who work in the core course areas that are often undervalued by their own departmental faculty (for example, writing composition, speech communication, and developmental mathematics). A sea change in representation cannot come fast enough and can be accomplished only through continued attention to the whole professoriate and educating the academic community and the public at every turn. Developers can examine their own literature, priorities, and 
programmatic assumptions to make sure that they are not making harmful delineations based on status in their own work.

Faculty studied were burdened by what they believed their tenure-line colleagues thought about them and their work. In some cases, their fears were validated through interactions; in others, the participants received recognition and appreciation from the tenure ranks. They were also concerned that these colleagues and others throughout the institution did not understand the course loads, salary structures, and appointment policies that FTNT faculty endured. Developers can help to create improved communication among the faculty to address these informational issues. They may organize mentoring arrangements or workshops at the campus or departmental levels to explore these topics, coordinate recognition for the contributions of FTNT faculty, and disseminate thoughtful articles about the differentiated but complementary work of all within the faculty community. Faculty need to know the roles and challenges of one another's positions, and developers can help to ensure that FTNT faculty receive opportunities to be judged on their own merits rather than on hierarchical notions of faculty appointments.

Findings indicate that many FTNT faculty members want a larger role in their institutions. Gappa et al. (2007) proposed that FTNT faculty need "opportunities to participate in governance, and recognition and rewards for contributions to the academic department or institution" (p. 209). FTNT faculty also need to take on a manageable amount of responsibility beyond the classroom as those who invest in this way will make certain that future campus decisions are not made without their input. Developers working at the organizational level can participate in policy discussions to help others see that disparities of eligibility should be addressed and that FTNT faculty should be encouraged to take available opportunities for participation.

\section{For Faculty Development}

Faculty developers need to recognize that the number of FTNT faculty has expanded to 30 percent nationwide and that they have become the majority of new full-time hires in academia (National Center for Education Statistics, 2005; Schuster \& Finklestein, 2006). They need to be aware of the composition of the FTNT faculty group, as well as those in other contingent categories. Developers must learn about the demographic variety within these populations and about the motivations and goals of their members. Through this empirical knowledge, academic developers will be prepared to act efficiently and appropriately to meet 
the educational and organizational needs of FTNT faculty and will be able to respond to new challenges and work with institutional leaders to provide constructive solutions (Sorcinelli, Austin, Eddy, \& Beach, 2005). Understanding that many FTNT faculty place more value on their personal than professional lives might help developers to filter their expectations for faculty commitment and participation through a different lens. Developers might collaborate with human resource colleagues to develop work-life balance programs specifically geared to faculty. Recognizing that FTNT faculty struggle with lower salaries than their tenure-line peers, developers might consider compensating FTNT faculty for time they contribute to projects undertaken by their centers.

If they do not already, developers must see themselves as advocates for all faculty, especially those who are marginalized. As advocates, developers must take the lead in ensuring that the recommendations made regarding organizational development are acted on while at the same time making programming changes to serve FTNT faculty better. Furthermore, faculty developers can be at the center of creating campus climates that foster inclusiveness by creating opportunities for tenure-line and FTNT faculty to work together.

Academic developers should develop a comprehensive plan for FTNT faculty development to include non-tenure-track programs as well as additions to existing development activities. For example, an FTNT faculty learning community could help participants discuss many of the individual challenges they face while also creating cross-campus connections and overcoming isolation (Cox, 2004). Programming that addresses work-life balance, teaching and grading efficiency, scholarship of teaching and learning, and navigating the political climate of the academy will help to support FTNT faculty. In an effort to accommodate the many demands placed on FTNT faculty, offerings should be held at varying times and in several formats (for example, face-to-face, online seminar, and online selfpaced modules).

Encouraging better understanding of and recognition for FTNT faculty, meanwhile, could become among the objectives for new faculty orientation, awards programs, and department-specific activities. Teaching centers might consider offering small grants to support FTNT faculty who want to attend conferences related to teaching and learning. Listservs or other online communities to help build connections between FTNT and tenureline faculty also could be useful.

While programs that integrate faculty across appointment types are very important, developers might also consider offering workshops or facilitated conversations specifically designed for FTNT faculty. These could 
include panels of established FTNT faculty or discussions facilitated by new and longer-serving FTNT faculty members. Open-ended questions, structured reflection, and self-assessment activities could help participants understand challenges and triumphs that cut across the group and those that they may find are theirs alone. Such workshops might explore the trade-offs that FTNT faculty make in order to create deeper conviction and satisfaction among those who feel that the choice is right for them, and brainstorm alternatives for those who are dissatisfied.

A multipronged approach would target both FTNT faculty and tenuretrack perceptions and would benefit institutions, FTNT faculty, the students they teach, and the tenure-line faculty who are their colleagues within the professoriate.

\section{Conclusion}

The findings of this study inevitably lead to concern about the sincerity of the lofty values professed by our academic system. One of the study participants expressed it well:

How do I put this? Are [tenure-line and FTNT faculty] equals? No. Is there a power difference? Yes. [Laugh] Because this is the truth about university life. We preach diversity here, right? And egalitarian qualities. But the truth is, universities, in many ways, are the very worst institutions for institutionalizing a hierarchy where some people are considered more valuable than others. Even though that's not what we preach to our students. It's very funny to me.

FTNT faculty in this study sacrificed personal time to grade paper after paper, published numerous books, and pushed the limits of what FTNT faculty could and could not do on their campuses. These individuals were deeply committed to higher education, put their students before themselves, and loved their work. Developers, with their commitment to improving the academy, should be among the first to appreciate those who choose FTNT careers and the many contributions these faculty make. Developers should also recognize and address the realities of the FTNT faculty, which can include shocking workloads, staggeringly low salaries, institutions' refusal to initiate promotion structures, the burden of the not-tenure-eligible branding, and unkind words of colleagues and leaders.

Developers are positioned to use knowledge about FTNT faculty to lead discussions that go to the heart of how faculty are thought of in America. Discussions, which can be initiated by academic developers, must 
be broad and include contemplation of whether tenure still makes sense. Furthermore, academic developers can work to ensure that all parties are at the table, not just those in the tenure ranks. Policies about faculty appointments cannot be one size fits all, as was made abundantly clear by the specific challenges faced by FTNT faculty in English. Proposals can consider institutional needs and tenured faculty, but they must also value individuals serving their institutions so well in their nontenured capacities.

Knowledge of the experiences of FTNT faculty, the work of concerned national organizations, and the research of many scholars interested in this issue provide the tools necessary for reconsidering and reconfiguring FTNT faculty work life. FTNT faculty, meanwhile, are using their voices, words, and actions to speak out about the realities of their work through publications, conferences, and faculty unions. Only by working together can optimal solutions be found and appropriate policies be developed for the new landscape of professorial life.

\section{REFERENCES}

AFT Higher Education. (2009). American academic: The state of the higher education workforce 1997-2007. Washington, DC: American Federation of Teachers.

Association of Departments of English. (1999). Report of the ADE Ad Hoc Committee on Staffing. ADE Bulletin, 122, 3-26.

Association of Public and Land-Grant Universities. (2009). Coping strategies of public universities during the recession of 2009: Results of a survey on the impact of the financial crisis on university campuses. Washington, DC: Author.

Baldwin, R. G., \& Chronister, J. L. (2001). Teaching without tenure: Policies and practices for a new era. Baltimore: Johns Hopkins University Press.

Bland, C. J., Center, B. A., Finstad, D. A., Risbey, K. R., \& Staples, J. (2006). The impact of appointment type on the productivity and commitment of full-time faculty in research and doctoral institutions. Journal of Higher Education, 77(1), 90-123.

Bousquet, M., Scott, T., \& Parascondola, L. (Eds.). (2004). Tenured bosses and disposable teachers: Writing instruction in the managed university.

Carbondale: Southern Illinois University Press.

Carspecken, P. F. (1996). Critical ethnography in educational research: A theoretical and practical guide. New York: Routledge.

Cayton, M. K. (1991). Writing as outsiders: Academic discourse and marginalized faculty. College English, 53(6), 647-660. 
Center for the Education of Women. (2007). Making the best of both worlds: Findings from a national institution-level survey on non-tenure track faculty. Ann Arbor, MI: Author.

Chait, R. P. (Ed.). (2002). The questions of tenure. Cambridge, MA: Harvard University Press.

Cox, M. D. (2004). Introduction to faculty learning communities. In M. D. Cox \& L. Richlin (Eds.), New directions for teaching and learning: Vol. 97. Building faculty learning communities (pp. 5-23). San Francisco: Jossey-Bass.

Creswell, J. W. (1998). Qualitative inquiry and research design: Choosing among five approaches. Thousand Oaks, CA: Sage.

Creswell, J. W. (2003). Research design: Qualitative, quantitative, and mixed method approaches (2nd ed.). Thousand Oaks, CA: Sage.

Ehrenberg, R. G., \& Zhang, L. (2005). Do tenured and tenure-track faculty matter? Journal of Human Resources, 40(3), 647-659.

Evans, L. C. (1996). An examination of the expectations between core and peripheral workers. Unpublished doctoral dissertation, Iowa State University, Ames.

Finkin, M. W. (1996). The case for tenure. Ithaca, NY: Cornell University Press. Gappa, J. M., Austin, A. E., \& Trice, A. G. (2007). Rethinking faculty work: Higher education's strategic imperative. San Francisco: Jossey-Bass.

Harper, E. P., Baldwin, R. G., Gansneder, B. G., \& Chronister, J. L. (2001). Fulltime women faculty off the tenure-track: Profile and practice. Review of Higher Education, 24(3), 237-257.

Kvale, S. (1996). InterViews: An introduction to qualitative interviewing. Thousand Oaks, CA: Sage.

Laurence, D. (2001). The 1999 MLA survey of staffing in English and foreign languages. New York: Modern Language Association.

Levin, J. S., Shaker, G. G., \& Wagoner, R. (2010, January). Post-neoliberalism: The professional identity of faculty off the tenure-track. Paper presented at the Global Collaboration Conference Series, Centre for Social Innovation and Education, Monash University, Melbourne, Australia.

McPherson, M. S., \& Schapiro, M. O. (1999). Tenure issues in higher education. Journal of Economic Perspectives, 13(1), 85-98.

Modern Language Association \& Association of Departments of English. (2008). Education in the balance: A report on the academic workforce in English. New York: Author.

Moustakas, C. (1994). Phenomenological research methods. Thousand Oaks, CA: Sage.

National Center for Education Statistics. (2005). 2004 national study of postsecondary faculty (NSOPF: 05): Data file. Washington, DC: U.S. Department of Education. 
Patton, M. Q. (2002). Qualitative research and evaluation methods (3rd ed.). Thousand Oaks, CA: Sage.

Plater, W. M. (2008). The twenty-first-century professoriate. Academe, 94(4), 34-40.

Rhoades, G., \& Maitland, C. (2008). Bargaining for full-time, non-tenure track faculty: Best practices. In The NEA 2008 Almanac of Higher Education. Retrieved from www2.nea.org/he/healma2k8/images/a08p67.pdf

Rice, R. E. (2006). From Athens to Berlin to L.A.: Faculty work and the new academy. Liberal Education, 92(4), 6-13.

Roemer, R. E., \& Schnitz, J. E. (1982). Academic employment as day labor: The dual labor market in higher education. Journal of Higher Education, 53(5), 514-531.

Rosenblum, G., \& Rosenblum, B. R. (1996). The flow of instructors through the segmented labor markets of academe. Higher Education, 31(5), 429-445.

Schuster, J. H., \& Finkelstein, M. J. (2006). The restructuring of academic work and careers. Baltimore: Johns Hopkins University Press.

Shaker, G. G. (2008). Off the track: The experience of being full-time non-tenuretrack in English (Unpublished doctoral dissertation). Indiana University, Bloomington.

Smith, C. B., \& Hixson, V. S. (1987). The work of the university professor: Evidence of segmented labor markets inside the academy. In H. Z. Lopata (Ed.), Current research on occupations and professions (Vol. 4, pp. 159180). Greenwich, CT: JAI Press.

Sorcinelli, M. D., Austin, A. E., Eddy, P. L., \& Beach, A. L. (2005). Creating the future of faculty development: Learning from the past, understanding the present. San Francisco: Jossey-Bass/Anker.

Tolbert, P. S. (1998). Two-tiered faculty systems and organizational outcomes. In D. W. Leslie (Ed.), New directions for higher education: Vol. 10. The growing use of part-time faculty: Understanding causes and effects (pp. 71-80). San Francisco: Jossey-Bass. 